This item was submitted to Loughborough's Research Repository by the author.

Items in Figshare are protected by copyright, with all rights reserved, unless otherwise indicated.

\title{
Mathematics and its value for engineering students: what are the implications for teaching?
}

\section{PLEASE CITE THE PUBLISHED VERSION}

http://dx.doi.org/10.1080/0020739X.2014.979893

\section{PUBLISHER}

(C) Taylor and Francis Ltd.

\section{VERSION}

AM (Accepted Manuscript)

\section{PUBLISHER STATEMENT}

This work is made available according to the conditions of the Creative Commons Attribution-NonCommercialNoDerivatives 4.0 International (CC BY-NC-ND 4.0) licence. Full details of this licence are available at: https://creativecommons.org/licenses/by-nc-nd/4.0/

\section{LICENCE}

CC BY-NC-ND 4.0

\section{REPOSITORY RECORD}

Harris, Diane, Laura Black, Paul Hernandez-Martinez, Birgit Pepin, Julian Williams, and TransMath Team. 2019. "Mathematics and Its Value for Engineering Students: What Are the Implications for Teaching?". figshare. https://hdl.handle.net/2134/17504. 


\title{
Mathematics and its value for engineering students: what are the implications for teaching?
}

Dr Diane Harris, University of Manchester (corresponding author)

Dr Laura Black, University of Manchester

Dr Paul Hernandez-Martinez, Loughborough University

Professor Birgit Pepin, University College Sør-Trøndelag in Trondheim, Norway

Professor Julian Williams, University of Manchester

with the TransMaths Team

School of Education, University of Manchester, UK

\begin{abstract}
Mathematics has long been known to be problematic for university engineering students and their teachers, for example Scanlan [1]. This paper presents recent data gathered from interviews with engineering students who experienced problems with mathematics and their lecturers during their transition through the first year in different programme contexts. Our interviews with the students reveal how they understand the relation between engineering and mathematics and we draw on the concept of árse- and exchange-valueôto explore this relationship more fully. This paper challenges both the pedagogical practice of teaching non-contextualized mathematics and also the lack of transparency regarding the significance of mathematics to engineering. We conclude that the value of mathematics in engineering remains a central problem, and argue that mathematics should be a fundamental concern in the design and practice of first year engineering.
\end{abstract}

Key words: mathematics, engineering, Higher Education, transition, problems

\section{Introduction}

There is a widely understood need for professional engineers and student óbecoming engineersôto think mathematically and to use mathematics to describe and analyse different aspects of the real world they seek to engineer. One thinks of the dynamics of structures and industrial fluid mechanics in the engineering of bridges, for instance, and the Tacoma bridge disaster.

Mathematical modelling therefore plays a key role in the formation of engineers, and there has been much research into how engineers should be taught the essential 
mathematics that spans some twenty years. In sum, this suggests that: engineers should be involved in teaching mathematics to student engineers; engineers should also óverseeô mathematicians teaching mathematics to student engineers; mathematics should be taught within an engineering context; and problem-based and problem solving or modelling courses are required. Yet, as we shall show, it seems from our case studies, the lessons of this literature have not been learnt, and furthermore, whichever way the mathematics within engineering courses is taught, there are problems for some students. The aim of this paper is to shed new light on this problem.

In this paper we report findings from our project [2] that included case studies of student transition to engineering degree courses (among other courses in STEM). This included surveying a total of 1,778 students (290 from engineering programmes) and interviewing 110 students ( 30 from engineering programmes) before they began their course, as well as during their first year and the beginning of their second year of study. The number of participants in the survey and the number of interviewees decreased as the project progressed due to student attrition (for example, students changing programmes or leaving the universities). For a quantitative analysis of the survey data, please refer to [3]. An interesting anecdote: we found some reluctance from engineering departments to contact their upcoming students with a survey about mathematics, as there was concern that the idea they would have to study mathematics might put them off coming. In general we found that the high mathematical content of engineering programmes came as a (usually unwelcome) surprise to many students when they arrived at university and, for many, mathematics proved a problem in their first year. Academic staff are well aware of this issue: and in all the case studies we made we found some efforts to help students which were not always successful.

One theme we found significant in our work was the various óaluesôthat students and lecturers ascribed to mathematical knowledge and know-how: as an important tool used by competent engineers (use value) but also as a signal of academic and professional distinction that employers pay good salaries to recruit (exchange value).

Therefore, in this paper, we investigate not only the pedagogical practice of teaching mathematics to engineering students, but also offer a lens through which to examine the value of mathematics for engineering.

\section{Theorisation of teaching/learning mathematics for engineering}

There have been various studies into the transfer of specific mathematics skills and/or mathematical knowledge by university students into new subject areas, including science [4] and engineering [5-7] who all report that students can experience problems in transferring these core skills to difference contexts. Thus, mathematics is not generally like a áoolôthat can be picked up and applied in various places without adjustment, modelling, and even sometimes rebuilding oneôs mathematical knowledge.

In fact, Cobb [8] and Walkerdine [9] suggest that the success (or not) of the transfer process is governed by the studentôs own goals and beliefs which shape their affective and ultimately cognitive engagement with mathematics. They further propose that many of the factors which influence a student $\hat{Q}$ ability to transfer mathematical 
knowledge and skills are in fact social in origin and have very little to do with mathematical aptitude. In this view, it is likely to be studentsôdispositions towards mathematics that counts $\ddot{i}$ alas, our work showed that the attitudes of these engineers to studying mathematics declined through the first year or so of their studies.[10]

In addition, Boaler [11] explains that students need specific help to learn to make connections between the original learning task/context (mathematics) and the application task/context (engineering). This is because, as findings reiterated by Putnam and Borko [12,p.4] suggest, "How a person learns a particular set of knowledge and skills, and the situation in which a person learns become a fundamental part of what is learned." Thus, presented with a new situation, engineering requires problem solving and modelling, not just ápplyingômathematics (see [13]).

The debate into how engineers should be taught mathematics has rumbled on for some twenty five years. One of the original participants, Scanlan [1], explained how the teaching of mathematics needs to be negotiated by engineers with the mathematicians who, he assumed, óserviceômathematics teaching:

ñThis is where the engineering department must have a clear understanding of what is needed and be able to communicate this effectively to the mathematicians. This dialogue should emphasize that mathematics in engineering is an essential part of the students' ớormationô (not a set of áoolsô to be acquired before proceeding to the ámportantôpart of the course), which cannot be separated from the other aspects provided by the engineering side.ò[1,p.449]

More recently, in research carried out by Bingolbali and Ozmantar [14], it was suggested that there is a dichotomy in the approach adopted by lecturers involved in delivering mathematics as a separate or óerviceôsubject: some see it as an element of engineering, yet others see it as a subject that needs to be taught in its own right which may therefore have little connection with engineering, especially in terms of contextually appropriate examples. Further, their research suggests that lecturers teaching mathematics as a service subject should not be left to their own devices, but should be offered guidance to help them attend to the practical mathematical needs of the engineering students.[14,p.615]

Whether students study mathematics in school, college or university, research indicates that there is a need for more inclusive and connected pedagogic practices.[15,16] In addition, studentsô mathematical understanding is always essential and generally more emphasis should be placed on relational (knowing why things work as they do) understanding rather than only procedural (knowing how to do something) mathematics.[17]

Swan [18] highlighted the distinction between a áransmissionistô and áonnectionistô pedagogy. In the former approach to teaching working through examples and teacher explanations are prevalent and teaching focuses mostly on procedural outcomes. In the connectionist approach students collaborate together on challenging tasks that emphasize the interconnected nature of mathematics, often involving discussion, and teaching focuses more on conceptual understanding. The latter approach builds on studentsôprior knowledge and enables them more readily to 
find solutions to practical, challenging and non-routine problems, which is desirable in engineering. Of course, learners require both procedural and conceptual understandings, but research has shown that current teaching-to-the-test pedagogy overwhelmingly emphasises the former. Connectionist teaching and the meaningful use of mathematics was also advocated by the Teaching and Learning Research Programme (hereafter TLRP) to aid both studentsôunderstanding of mathematics and their disposition towards the subject.[19,20] These findings have also been reiterated in the Project.[10]

A more unified approach is advocated by Flegg et al. [21] who suggest the use of problem-based tasks which have been developed by engineers and mathematicians working collaboratively together towards the design of the engineering programme. They believe that this would enable the students to appreciate the relevance of mathematics in their future studies and careers.[21]

However, there remains the issue raised by Biggs [22,23] and Hoyles et al. [24] namely that the transition into Higher Education can be particularly difficult for some students and that it can be helpful to align practices either side of the transition. This is probably why there remains disagreement about the way in which the mathematics elements of engineering programmes are taught: mathematics specifically for engineering is rarely taught prior to the transition (except in the vocational programmes, which remain the minority).

In order to help us to understand the teaching of mathematics to prospective engineering students, and indeed teaching in general, we seek to understand the values that motivate students, their teachers, and indeed the institutions in which they work together. On the one hand all seem to understand (and often say in their interviews) how important mathematics is because it is ássefulô and understanding and becoming skilled at mathematics should empower students in their lives, including their future studies and work. On the other hand, a mathematics grade or qualification is required for many prestigious or high status courses and is thereby ultimately áxchangeableô for a well-paid job. This dichotomy is explained by Black et al. [25,p.70-71]:

ñ..mathematics in the education system has an elite status or currency assigned to it which is mostly disconnected from its eventual óiseô in the labour market...This detachment of its exchange value from its eventual áseôraises all kinds of tensions which may be applicable to only a small number of school subjects... Consequently, we suggest that programmes which emphasise the áıse-valueô of mathematics...may be crucial in enabling students to manage such tensions and contradictions.ò

The utility and power of mathematics on the one hand and its currency on the job market and value to the economy and society are not unrelated: but they are not the same thing, and can actually be contradictory! We reported many instances of this in schools and colleges: learners and teachers may focus on procedures to get a good grade in the test, even at the expense of the long term value of understanding mathematics; and this is welcomed by the college management who measure efficacy (and their league table position, and so earned income) by the grades the students achieve.[19]

The teachers and principals, who were interviewed as part of the TLRP Project [19], talked about mathematics almost exclusively in terms of grades and qualifications i.e. 
its exchange-value. In describing exchange-value, Gibbins [26] explains it as the property of a commodity that regulates its capacity to be exchanged. In this context, a mathematical qualification has exchange-value because it may be exchanged for additional education or added value in subsequent employment in a workplace. A disturbing element of this discourse was that it was revealed that in order to optimise their grades, students were sometimes persuaded to ñdropò mathematics rather than invest time in a subject where they were destined not to succeed or, at least, realize little currency for their future educational and career aspirations.[27]

Similarly, in our cases of engineering mathematics in Higher Education, a mathematics module grade may have use-value if it represents learning that enables the students to perform mathematics in engineering tasks and so supports them in their engineering studies and future work. But its exchange value depends on how it is valued in the institution and later on in the job market: in some professional accreditation systems a certain level of mathematics is prescribed, and it certainly has high exchange value.

\section{The Research Methodology}

The Project [2] focused on transitional practices between sixth form college or college of further education and Higher Education. The aim was to follow studentsô experiences of and engagement with mathematics and how these shape their developing dispositions toward mathematics and 'identityôas learners of mathematics. The research involved the examination of thirteen degree programmes across five English universities.

Three of our universities had engineering programmes and the research team interviewed students and staff from all three in order to gain an overview of the various transitional practices adopted to help their new engineering students. Apart from revealing their own attitudes towards the mathematics in their respective engineering courses, the student interviews also expose the transitional mathematics practices which take place on the course and at the universities involved in the project and, in particular, how these practices are perceived to help or hinder the mathematically dess well-preparedô student. These include diagnostic testing and subsequent ábility groupingô of students for mathematics, encouraging students to attend mathematics/learning resource centres and mathematics drop-in centres, or practice using online mathematics materials and peer-assisted student support (PASS).

The óbecoming engineersô were tracked longitudinally until the end of their first year at university and may therefore be described as being in transition from student in sixth form college or college of further education, to student engineer in university. By choosing to study engineering, students are selecting courses which are mathematically demanding and subsequently this selection may influence their overall success or failure on the course.

During this time the students completed three surveys which explored their disposition towards mathematics. The case studies also investigated educational 
(transition) practices based on observation, documentary analysis and student and lecturer interviews. These interviews revealed studentsô experiences of and their engagement with mathematics and how these shape their disposition towards their respective engineering courses in general and mathematics in particular.

The students who were interviewed were volunteers and were all asked the same questions as set out in a pre-prepared interview schedule and all the student interviews (some of which were quite substantial) were then transcribed. For the present analysis, all utterances that implicitly or explicitly referred to a q́problemôwith the teaching of mathematics were selected for thematic analysis. The quotations and short extracts included in this paper therefore focus on studentsôperceptions of problematic mathematics learning experiences and also serve to provide óglimpsesôinto studentsô expectations of teaching/learning within engineering courses in Higher Education. More information about the research project is available online at: www.transmaths.org

All the students were interviewed on three occasions during their first fifteen months at university: either just before starting or during the first few weeks of the course; after their first set of half-yearly examinations; and finally at the beginning of their second year. The interview questions provide the opportunity to explore the problems which faced the students in their study of mathematics as they progressed through their engineering courses, with the majority of the extracts being taken from second and third interviews when the students were in a position to reflect both on their school and university experiences of mathematics. Thematic analysis of the interview data revealed that there were two recurring areas where the engineering students identify problems with mathematics. The rationale for this paper is therefore to explore and reflect on the studentsôconcerns in more detail by addressing the following research questions:

a) What problems are encountered by the students due to the unexpected extent of mathematics within the engineering programmes? and

b) In what ways do the students find that the separation of mathematics from engineering is a problem?

In addition to the student interviews, nine lecturers involved with the engineering programmes also volunteered to be interviewed about the challenges of teaching mathematics to engineering students and three of these are also used here. In the following discussion, the names of the three lecturers and nine students have been changed to protect their identities but the pseudonyms do indicate gender and race. The universities have also been given pseudonyms. The students and lecturers are from three universities which all teach mathematics as a separate subject in order to convey the mathematical elements of their engineering programmes. In the two traditional universities (óNorthernô and đ̊Riversideô), mathematics is taught by mathematicians but in the post-92 university (óModernô,, the mathematics is taught by engineers.

\section{The Findings}


In the following discussion: students George, Liam and Joshua are from óNorthernô students Ellie, Owen and Sam are from đ́Riversideôand Halim, James and Stuart are from óModernô Lecturers Peter, Mark and Andrew are from óNorthernô óRiversideô and óModernôrespectively. Short extracts from the interview transcripts are provided.

\section{a) What problems are encountered by the students due to the unexpected extent of mathematics within the engineering programmes?}

One of the lecturers and several of the students told us about the lack of information available to students before they commenced their engineering studies at university: the high mathematical content of many of the engineering programmes appears to be minimised. An explanation for this may be that potential students are not deterred from applying and therefore the reasoning behind this may be financial i.e. more students equals more money, in the belief that the university mathematicians will be able to sort out any weaknesses during the studentsôfirst year.

Peter, a lecturer at óNorthernôwho teaches both engineering and mathematics, is well aware of the fact that students do not expect to be studying so much mathematics when they have enrolled for a degree in engineering. He explains the effect that this has on both the students and his teaching:

Peter: Well we constantly tell them as we go through the curriculum and we slot in perhaps hypothetical and simplistic connections with the course, but we tell them, Iôm constantly telling them that verbally, about how this is important. But that is something that weôe recognised over the last two or three years really, the students want to know é why theyốe doing maths. They arrive at university thinking that theyôe signed up for an [engineering] degree, and then they find theyốe doing mathematics, so itôs very important for them to understand why theyốe doing mathematics and that it does matter. If youôre going to be an engineer, you need to be able to quantify things.

With much of the mathematics being taught essentially as a separate subject, Peter finds that it is necessary to give his students reassurance that the mathematics will be useful i.e. have use-value in their engineering degrees. This has become more of a concern for the students over the last three years which is possibly more to do with the rise in student fees than anything else because the students want to maximise their investment i.e. for mathematics to have an exchange-value in terms of career prospects, financial rewards etc. When asked by the interviewer if he thinks that the amount of mathematics comes as a ñshockò for the students, he replies:

Peter: I think itô a shock for some students. I think some students think theyôe going to come and spend a lot of time in the laboratory and make things with flashing lights and transistors, and thatố all theyốe going to do, but actually electronic engineering is very deep, mathematically difficult, you know, rock hard engineering course, and itôs getting harder, not easier. The breadth of the curriculum gets constantly wider and the impact it has on society is only growing year by year, not diminishing.

Peter explains that the students are surprised because engineering is not what they expected; they expected that they would be spending time in the laboratory making things. The reality is that the subject is becoming both broader and harder and 
therefore óNorthernô has a ñock hard engineering courseò to support this which therefore has exchange-value at the end of the degree.

Halim, when he described his first year, gave some perspective on how different an engineering course can be from other university subjects and provide some insight into what a ñock hard engineering courseò (Peterôs phrase!) might be like to experience. He is at óModernôand had some experience of engineering at college. Halim knew that mathematics would be involved although he believes that the university did not explain the óntensityôof the degree:

Interviewer: But at the beginning when we just started you said that itô harder than you expected it to be.

Halim: It is a lot harder.

Interviewer: So you didnâ know that engineering involved this?

Halim: $\quad$ Yeah because itôs funny how they kind of fail to mention thatð

Interviewer: You mean the course developers or the people whoð

Halim: The university. As in theyôl say to you, engineering, wow, weôre got this course-

Interviewer: And they donâ mention mathematics then?

Halim: Oh no, they mention mathematics áause I know áause I did engineering at college. I know thereôs mathematics but they donâ mention the intensity of the course compared to other courses ... Everyone says the first year at university is a blast - itôs not when youôe doing engineering ... I donâ know any other people that have had as many exams as me: any other people from any other subjects, already. You know and theyốe saying, óoh Iôe got my first examôand theyôre all like, and Iôm like, ñiôe bloody had eight already!ò You get used to it, you know ácause it is very scary as well to think you know, am I gonna fail this first year? Am I gonna be able to keep up?

It therefore seems that the pressure is on robecoming engineersò from the outset of their degrees with a constant threat of failure looming over their heads. Sometimes this pressure does become too great and the student has no real option other than to leave. This happened to James who is now studying engineering at óModernô Having left an engineering degree at óRiversideô because he found the mathematics too difficult, James now appreciates the exchange-value of an engineering degree with high mathematical content. He explains:

James: $\quad$ Yeah, I started again at óModernô because one of the reasons was finding the maths so difficult at óRiversideô Erm, and since being here the level of maths is completely different.

Interviewer: Any regrets so far?

James: $\quad$ Erm, in some ways I wish I, er, did have had a better understanding in maths and did have continued at óRiversideôbecause, I mean, obviously the degree is worth more thanð

Interviewer: So you wanted to stay there?

James: $\quad$ Yeah if I, if I had a better understanding of maths.

Interviewer: So what do you mean, the degree was worth more?

James: $\quad$ Err, I donâ know just iné in terms ofð

Interviewer: Employability?

James: $\quad$ By leaving a better university than óModernôI guess.

Interviewer: So the reason you turned to this university was because of the maths actually?

James: Yeah, yeah.

Interviewer: Erm, do you think mathematics, now that you donô do so much, mathematics will be useful in the future in your degree, or you donâ see any relevance still? 
James: $\quad$ Erm, I think it will be important to do more maths than we are here, you know, Iôd be happy to do some more maths ... a bit more, but not to óRiversideôlevel. I think itôs important.

Interviewer: So have your feelings towards mathematics changed during this year now you donâ do so much maths?

James: $\quad$ Well, it used to be annoying that we had so much, but I think itôs the other way round. It will be good to have more, because, you know. Itôs so important. Itố good, just brain-training. Itôs good.

James explained that his friends had similarly struggled with the mathematicallydemanding engineering course at óRiversideô but they had persisted and he now seemed to have appreciated the value of the difficult mathematics at đ́Riversideô By moving universities and taking a course with easier mathematics, James had ñtraded inò a portion of the exchange-value of his degree, although he would not be drawn on the fact that it may have affected his employability. His explanation that he would like to do more mathematics because it was ñbrain-trainingò seems to belie his statement, ôt will be important to do more maths than we are hereô The future tense here suggests career prospects rather than the use-value of mathematics for the engineering course.

Ellie was surprised by the amount of mathematics within her engineering degree at đ́Riversideô She had chosen engineering because she had been led to believe that it would be more ñinterestingò than mathematics and so was surprised to find that it included so much mathematics:

Ellie: $\quad$ So I knew there would be a lot of maths. Probably I wouldnâ have picked the course if I was literally gonna do a maths degree.

At ómodernô Stuart would also have taken a different course if he had known how much mathematics was involved in his engineering degree. Furthermore, he seemed to suspect some sort of conspiracy whereby unsuspecting students were lured into engineering programmes by the university using non-mathematics sounding names to disguise the mathematics modules:

Stuart: I think, when they signed up for the course, they did not accurately represent how much maths there would be. é .

Interviewer: So you didnâ check the specifications of the course before?

Stuart: $\quad$ To be honest I read over everything there was.

Interviewer: On the website?

Stuart: $\quad$ And it just said the module units but it didnâ explain like engineering problem solving is just maths, thereôs nothing else. Now when I did engineering problem solving in college, there was a little bit of maths but there was a lot of practical. Finding a fault with the circuit and fixing it. Thereôs none of that here.

Interviewer: So if you knew from the beginning...?

Stuart: Iôl have taken a different course.

Many of the becoming engineersò said they did not expect so much mathematics within their engineering courses. Either by the students misunderstanding the titles given to the elements of their degrees or, as Halim and Stuart believe, by being deliberately misled, they find their engineering degree programmes mathematically demanding. James, who has had experience of two different universities, a traditional and a post-92 institution, now seems to perceive the exchange-value of a more 
mathematically challenging degree. For the other students, the mathematics and the amount of work in general has come as a surprise. This in itself suggests that the problems of mathematics-in-engineering start in school and society, and that there are therefore wider educational issues at stake. It is not just that mathematics is taught separately at university, but that mathematics is separated from problem solving and cultural activity everywhere: as in school, so in life.

\section{b) In what ways do the students find that the separation of mathematics from engineering is a problem?}

The need to succeed in mathematics is apparent to the majority of students although some find it extremely difficult particularly because, in many cases, the mathematics is taught separately from the engineering. The students feel that there is a lack of cohesion between the mathematics being taught and the engineering that it supports. The separateness of mathematics has implications for how the subject is presented to the students i.e. in terms of use- and exchange-value.

In the following extract Ellie, a student at óRiversideôUniversity, reflects on the mathematics taught in her engineering course and also expresses views on the way that her group are taught mathematics in a service course with other engineering disciplines. The interviewer asks Ellie whether she considers that mathematics is important:

Ellie: I donâ think like, in the first semester it was emphasised how important maths is to the engineering subjects. I think it was treated far too, treated far too separate. I know like obviously maybe for like numbers and things, they have to put us in with the [other engineering disciplines] for maths but I donâ know if thatô a very good idea, because itô like, I think it should be much more combined. I didnâ expect when I came here that my maths would be like, itô just a separate subject. I thought it would be completely applied to what I was doing and it wasnâ.

The separateness of the mathematics and engineering courses has come as a surprise to Ellie as she says that she ómay as well have signed up for a degree in mathematicsô because of the way in which the engineering course is structured i.e. mathematics as a separate subject. This separation of the two subjects also means that there needs to be close collaboration between engineering and service mathematics at óRiversideô Mark, a lecturer in engineering at óRiversideô explains that to ógetô electrical field theory the students need the mental agility to hold several ideas in their minds at the same time, in particular spatial concepts and mathematical concepts. Therefore the students need to have already covered the necessary mathematics in order to make sense of electrical field theory. When asked for an example, Mark described what is entailed in calculating the flux generated by a wire.

Mark: $\quad$ So you have to be able to think about the direction of the flux, and thatô three dimensional, and you have to think about what type of surfaces are best to use if itôs wire which is a cylinder because that exploits the symmetry and then you have to be able to picture the pattern of the flux that would be generated by the wire, and how that passes out of the cylinder. And once you get the idea; you can see that the ends of the cylinder have no contribution. The flux is parallel to the ends so nothing leaves through them and all the flux must leave through the curved surface. So you have to be able to think spatially to see this, but then you also have to translate those 
ideas into the mathematics, into the algebra as well, to work out the flux density times the surface equals the charge, so you have to be able to do that side of it as well. You have to be able to get those concepts together, and once you get them theyốe obvious. If you donâ get them it just seems like a, it almost seems like an alien language and so, you know, some people see it straight away and others really have to think about it before they get it.

From this explanation, it is obvious that in order to teach electric field theory, the students already need to have a working knowledge of algebra, geometry and vectors but, for those students who have not gained these mathematical skills, Mark acknowledges that the topic must seem like an álien languageô It appears, however, that this does not always happen because Sam, a student at đ̛Riversideô talks about the separateness of the mathematics and engineering courses and his demand for more ñink-upò suggests a demand for more use-value:

Sam: $\quad$ Even just between two courses [mathematics and engineering] they donâ quite know what the other oneôs taught so sometimes theyôre repeating stuff, sometimes theyôe assuming stuff. It could do with being a little more link-up between the courses.

At ómodernô there seems to be an issue with the relevancy of the mathematics that is taught to support the engineering courses. Informal conversations with staff members suggested that they do not want to overload their students with irrelevant and unnecessary mathematics because they want to keep the mathematics to a minimum. Andrew, a lecturer at óModernô explained how this might be achieved within an engineering context:

Andrew: Well the maths is relevant, I donâ think they see it as superfluous if itôs relevant and useful to them. We teach suspension system modelling to students and as part of that theyôre got to understand that road data is completely non uniform and they have to have a Fourier Transform to make it into something you can represent by an equation and theyôre quite happy to go through the process. If I was to turn up and say today weôe doing Fourier Transforms theyốl go, ñAre we on an electrical course or something? Why are we doing Fourier transforms, weôe mechanical engineers?ò but if they can see them as a really useful thing and that theyôre relevant, then theyâl get on and do it.

However Stuart, an engineering student at óModernô is unable to see the relevance of the mathematics he is studying because the links between the mathematics and engineering courses have not been made explicit in the way that the lecturer Andrew described. Again this suggests a request for more use-value. But this extract also suggests that Stuart fails to appreciate the value of a mathematically demanding course for his (or anybody elseôs) future career prospects:

Stuart: I donâ see the relevance. I mean I actually do enjoy maths sometimes as well but I just do not see the relevance of it. If they gave us some examples about why it might actually be useful then fair enough but just seeing somebody write a formula on a board and then going, ñsolve thatò, youôe like, óWhy? What possible point is it gonna have to me in the future?ô..

Interviewer: I see. So you need it to be relevant to your future career?

Stuart: Yeah relevant, or even relevant to somebody elseôs in the class future career. If I could see a use for it. 
At óNorthernô George was beginning to make the connections because when he was asked about whether he was using what he had learnt in mathematics in his engineering course, he was able to reply:

George: Yeah definitely. As I said, the lecturers are assuming we know more in lectures, and part of the thing that theyôe assuming is that we know a lot more maths, so already the lecturers are starting to apply maths that weôe learnt in the last few months. So you can definitely see where the applications are ... you can tell the importance of it. You can definitely see where the maths is gonna apply.

Georgê̂́ more positive view may be because the lecturers at óNorthernô ï as opposed to the service teaching at đ́Riversideô- provide the students with engineering context in the mathematics course problem sheets. This course was designed by the engineers to include examples of mathematics situated in engineering contexts/tasks in order to provide the students with a solid mathematical foundation for their engineering modules. This approach appears to be working because Joshua seemed to have the confidence and determination to tackle the examples:

Interviewer: Now, coming back to this, how does maths fits with the engineering? Is it up to you to use maths, or is it up to the lecturer to decide you can use Laplace Transforms here, oré ?

Joshua: He tends just to give us information without. Usually they wonâ provide anything and theyâl just say, ñYou know how to solve this and, to save time, this is the result if you doò. So, thatôs generally how they deal with it.

Interviewer: But letôs say you have an engineering problem of some sort, is it up to you to say, ñOh I can use Fourier hereò, or soé ?

Joshua: Usually, yeah. They donâ tell you how to do it. Itôs up to you which method you use. Sometimes, if itôs a more difficult one, theyâl put a hint in brackets afterwards and say how you could do it, but usually itôs not telling you how to solve it.

Interviewer: And is that easy for you? Or, how easy is to make the link?

Joshua: Well, itố better, because you donâ want to just be told how to solve these particular problems because the end of engineering is solving normal problems. So if youôe told how to do it, youôe not learning how to do engineering, youôe just learning how to do maths. So I donâ think it would be better to do it any other way.

Joshua seems very content with the way he is being taught the mathematics for his engineering course and can appreciate the rationale behind the pedagogical practices in place at óNorthernô Also, like James from óModernô Joshua seems to be thinking about his future career in engineering as a problem-solver rather than the use-value of mathematics for his current engineering course.

Another difference between óNorthernôand ớiversideôwas that one of the lecturers of the mathematics course there, Joanne, was also a teacher at a sixth form college and had been recruited to help the engineers teach mathematics to first year students. She was responsible for teaching mathematics to the less able group of first year engineering students and Joanneôs approach and experience was appreciated by her students, as Martha explained:

Martha: The maths was really, it was okay with Joanne because Joanne really helped us a lot in her class. Gave us examples and it really helped meé 
Using examples from engineering within the mathematics lectures also helped Ellieôs situation at óRiversideô when her group (comprising students from two engineering disciplines, labelled A and B) were given a new lecturer for mathematics. She explains the difference that this made to her studies:

Ellie: $\quad$ Iôe a new lecturer this term and he always teaches the maths and then he applies it to an example. So thatô really good, and then heâl apply it, áause we have maths with the [other disciplines of engineering] as well... So heâl do like [discipline A] example as well so like, I wouldnâ obviously write it down, Iôl just write down the [discipline B] one and obviously the same for them. So it is good, because it was like, it seemed really silly doing something when you donâ know what itôs applied to especially when this term, as well, thereôs a lot of like integration and stuff in the engineering subjects.

However, when Owen from đ́Riversideôwas asked about his choice of subject, he revealed that he had thought about the exchange value of mathematics but only when it is useful for his engineering:

Owen: $\quad$ Well if I'd chosen maths then I'd just come out with a maths degree and I might not know how to use it ... If I went into the workplace I'd probably spend longer in a training programme trying to learn how to use it and then I probably wouldn't enjoy it because I'm just learning maths and you don't really know how to use it. So it's not helpful to you if you're not actually using it for anything. You're not putting units in, so it's not giving the numbers meaning, so there's no point. Engineering- there's a shortage of engineers. I don't know I just enjoy it more. I don't know why, because it's not just maths, in engineering it's loads of other things as well, there's circuit analysis, there's, you've got to learn all the digital logic which is completely different and you're learning like working in different number bases and algebra and stuff like that.

Owen here speaks about engineering in terms of enjoyment (which may also be considered as use-value) but it was more common for the students to talk about mathematics in terms of its use as a means to an end to help them with their engineering. The use of mathematics was also sometimes attributable to the fact that a good A-level grade in mathematics could be exchanged for a place on a more esteemed university course (which we see as its exchange value). At university, the students find that the situation has changed and they are told their mathematics is needed and useful, and they are studying mathematics because of its use in their engineering degrees.

Also, in contrast to some of the previous research, however, we found that some students did not seem to be particularly concerned about being taught by mathematics lecturers providing they made the subject matter explicitly relevant to engineering. However, this is demanding for many mathematicians and those students taught by lecturers who do not make these connections did express dissatisfaction with this lack of connection,

\section{Discussion}

As in the literature previously discussed, the students revealed that mathematics and the way in which it is taught appear to cause the most problems for first year engineering students across all three universities. 
The study has gone some way towards enhancing our understanding of how much knowledge the students have about professional engineering in terms of its mathematical content before they enrolled for their degrees. It was surprising to learn that very few óbecoming engineersô realized how mathematically-demanding their courses would prove to be, and evidently some would not have chosen the course if they had known!

Furthermore, in school, Williams [27] reported that mathematics was all about its exchange-value as described by Gibbins [26]: grades and qualifications which could then be áxchangedôfor places at university $\ddot{i}$ the better the grades, the more áliteô the university [19]. The findings of this current study revealed that in engineering at university the discourse changed: mathematics was no longer being talked about in the same way. There remained an element of éxchange valueôi.e. the students were thinking about their long-term career prospects, but usually the students spoke about mathematics in terms of its use-value to support their engineering studies. The longer-term exchange value of mathematics seemed more difficult for them to comprehend at the early stage of their engineering programmes, but became evident for some of the more mature students or those with some years of study behind them like James.

Prior studies have reported on the dilemma regarding who are best equipped to teach mathematics to engineering students i.e. engineers or mathematicians $[1,14]$. Contrary to expectations, this study found that very few of the óbecoming engineersô expressed any concerns about this aspect of their courses. Boaler [11] reported that students need detailed help to make the connections between the original context (mathematics) and the application (engineering). This was corroborated by Joanne $\hat{Q}$ students at óNorthernôwho, although Joanne had no engineering training, she did her best to help the students in the way that she taught them the necessary mathematics. At the other extreme, we also interviewed lecturers who were adamant that students should learn mathematics for its own sake. Bingolbali and Ozmantar [14] suggest that this perspective places mathematics at the centre, as it were, rather than the needs and interests of the students. This issue is raised by many of our students when they talk about feeling insecure about the mathematics in part because they do not know how it will be useful in their engineering courses $i ̈$ often the links do not seem to be made explicit.

For our interviewees, the problems were most acute when the mathematics was taught without any reference to engineering, but we found that the situation was especially problematic in the absence of examples. This decontextualisation seemed to allow the mathematics to become disembedded from its use to engineering and therefore the opportunity to foster a perception of its áise-valueôin the wider sense was lost.

Interviews with lecturers and other teaching staff revealed that some of them were aware of the challenges faced by the students but, as individuals, very few seemed able to introduce truly integrated mathematics-with-engineering as described by Scanlan [1], presumably due to curriculum requirements, time constraints etc. That said, there were mathematics teachers who provided engineering contexts. These 
efforts were greatly appreciated by our interviewees (in particular Martha and Ellie) because they revealed how mathematics would be useful to the students in their engineering studies and future engineering careers.

We would therefore suggest teaching mathematics in a much more integrated way with the engineering always making the connections and motivating the mathematics, whether consolidating their previous work or inspiring the next stage of study of mathematics. By adopting this approach, it is hoped that studentsô dispositions to mathematics will improve, or at least will not decline, during their first year at university as was indicated by this current research.[10] Although we argued that some mathematics teachers can make good teachers of mathematics for engineers, it is always essential that engineers are involved in the design of the courses. We suggest that devolving the mathematics to others is a big mistake for engineering programmes, rather all tutors and lecturers need to make mathematical concerns central to all their teaching, especially those engineers teaching ángineeringôcourses.

\section{Conclusions}

It appears that the transfer of mathematics to the context of engineering seems problematic. Therefore this paper argues that mathematics should be embedded with the engineering principles being taught. There was a danger that when mathematics becomes isolated from its use in engineering, the opportunity to foster a perception of its use-value in the wider sense was lost. Implications are therefore raised regarding the pedagogic practices which prevail within engineering courses. Our research indicates that it would significantly improve studentsô perceptions if engineering programmes in Higher Education included discipline-appropriate engineering examples within the mathematics, at least. Our theoretical framework suggests, however, that all attempts to improve the engagement of óecoming engineersôwith mathematics need to consider the values associated with its áseô and @́xchangeô students who see themselves as engineers need especially to perceive the use of mathematics to their engineering, and this needs continual work. We argue this can only be achieved by engineers themselves designing the whole curriculum and its progression appropriately, though we do have some evidence that mathematics teachers can help, having expertise in the difficulties students experience at various levels.

Finally, at a national level, the UK government claims to need more and better engineers because, as reported by Castle [28] in the New York Times, the current shortage is placing a strain on the economy which could lead the country into further recession. The current study has gone some way towards enhancing our understanding of the problems that óbcoming engineersôexperience due to the mismatch between their expectations and the realities of the course, and has once again highlighted the fact that mathematics is central to these. Continuing effort is needed to make plain the value of mathematics to engineering in practice. 


\section{Acknowledgements}

As the author of this paper I recognize the contribution made by the team in collection of data, design of instruments and project, and discussions involving analyses and interpretations of the results. I would also like to acknowledge the support of the [Research Council].

\section{References}

[1] Scanlan JO. The role of mathematics in engineering education: an engineer's view. Int. J. Math. Educ. Sci. Technol. 1985;16:445-451.

[2] Williams J, Black L, Davis P, Pepin B, Wake G. Mathematics learning, identity and educational practice: the transition into Higher Education. ESRC End of Award Report, RES-062-23-1213; 2010.

[3] Pampaka M, Williams J. Hutcheson, G. Measuring studentsô transition into university and its association with learning outcomes. Brit. Educ. Res. J. 2012;38;1041ї 1071.

[4] Britton S, New PB, Sharma MD, Yardley D. A case study of the transfer of mathematics skills by university students. Int. J. Math. Educ. Sci. Technol. 2005;36:1-13.

[5] Hirst C, Williamson S, Bishop P. A holistic approach to mathematics support for engineering. In: Baillie C, Moore I, editors. Effective Learning and Teaching in Engineering. Abingdon, Oxon: Routledge; 2004. p. 100-122.

[6] Fadali M, Velasquez-Bryant N, Robinson M. Work in Progress - Is Attitude Toward Mathematics a Major Obstacle to Engineering Education? Paper presented at: The ASEE/IEEE Frontiers in Education Conference. 34th Annual Meeting; 2004 October 20-23; Savannah, GA. Available from: http://fieconference.org/fie2004/papers/1090.pdf

[7] Gynnild V, Tyssedal J, Lorentzen L. Approaches to study and the quality of learning. Some empirical evidence from engineering education. Int. J. Math. Educ. Sci. Technol. 2005; 3:587-607.

[8] Cobb P. Contexts, goals, beliefs and learning mathematics. For Learning Math. 1986;6:2-10.

[9] Walkerdine V. Difference, cognition and mathematics education. For Learning Math., 1990;10:51-56.

[10] Pampaka M, Williams J, Hutcheson G, Wake G, Black L, Davis P, Hernandez-Martinez P. The association between mathematics pedagogy and learners' dispositions for university study. Brit. Educ. Res. J. 2012;38:473496.

[11] Boaler J. Exploring situated insights into research and learning. J. Res. Math. Educ, 2000;39:113-119.

[12] Putnam R, Borko H. What do new views of knowledge and thinking have to say about research on teacher learning? Educ. Researcher. 2000;29:4-15.

[13] Williams J, Goos M. Modelling with mathematics and technologies. In: Clements K, Bishop A, Keitel C, Kilpatrick J, Leung F, editors. Third International Handbook of Mathematics Education. London: Springer; 2013, p. 549-571. 
[14] Bingolbali E, Ozmantar MF. Factors shaping mathematics lecturers' service teaching in different departments. Int. J. Math. Educ. Sci. Technol. 2009;40:597-617.

[15] Leinhardt G, Smith DA. Expertise in mathematics instruction: Subject matter knowledge. J. Educ. Psychol. 1985;3:247-271.

[16] Askew M, Brown M, Rhodes V, Wiliam D, Johnson D. Effective Teachers of Numeracy: Report of a study carried out for the Teacher Training Agency London: King's College, University of London; 1997.

[17] Skemp RR. Relational understanding and instrumental understanding. Arith. Teacher. 1978;26:9-15.

[18] Swan M. Improving Learning in Mathematics: Challenges and Strategies. London: Department for Education and Skills Standards Unit; 2005.

[19] TLRP Research Briefing 38: Keeping Open the Door to Mathematically Demanding Programmes in Further and Higher Education. London: Teaching and Learning Research Programme; 2008. Available at:

http://www.tlrp.org/pub/documents/ Williams\%20RB\%2038\%20FINAL.pdf

[20] Williams J, Black L, Davis P, Hernandez-Martinez P, Hutcheson G, Nicholson S, Pampaka M, Wake, G. Keeping open the doors to mathematically demanding programmes in further and higher education: a cultural model of value. In: David M, editor. Improving Learning by Widening Participation in Higher Education. đ́mproving Learning Gatewayô - Teaching \& Learning Research Programme. London: Routledge; 2009, p. 109-124.

[21] Flegg J, Mallet D, Lupton M. Studentsô perceptions of the relevance of mathematics in engineering. Int. J. Math. Educ. Sci. Technol. 2012;43:1-12.

[22] Biggs JB. Enhancing teaching through constructive alignment. Higher Educ. 1996;32:1-18.

[23] Biggs JB. Teaching for Quality Learning at University. 2nd ed. Buckingham: Open University Press/Society for Research into Higher Education; 2003.

[24] Hoyles C, Newman K, Noss R. Changing patterns of transition from school to university mathematics. Int. J. Math. Educ. Sci. Technol. 2001;32:829-845.

[25] Black L, Williams J, Hernandez-Martinez P, Davis P, Wake G. Developing a đ́eading identityô the relationship between studentsô mathematical identities and their career and higher education aspirations. Educ. Studies Math. 2010; 73:55-72.

[26] Gibbins P. Use-value and exchange-value. Theory Decis. 1976;7:171-179.

[27] Williams J. Toward a Political Economic Theory of Education: Use and Exchange Values of Enhanced Labor Power. Mind Cult. Activity. 2011;18: 276-292.

[28] Castle S. Shortage of engineers a strain on Britain's economy. New York Times [Internet]. 2013 Feb 3 [cited 2013 May 13];Research:[about 4 screens]. Available from: http://www.nytimes.com/2013/02/04/business/global/04iht-uk skills 04.html?pagewanted=all\&_r=0 